\title{
Cerebro arteriovenous malformation presenting as recurrent epistaxis: a rare entity
}

\author{
D. Manoj ${ }^{1}$, Venkatasuryanarayana ${ }^{2}$, C.R. Banapurmath ${ }^{3}$ \\ ${ }^{1}$ Dr. D. Manoj, Resident, ${ }^{2}$ Dr.Venkatasuryanarayana, Resident, ${ }^{3}$ Dr. C.R. Banapurmath, Professor; all authors are \\ affiliated with Department of Pediatrics, JJM Medical College, Davanagere, Karnataka, India.
}

Corresponding Author: Dr. D. Manoj, Resident, Department of Pediatrics, JJM Medical College, Davanagere, Karnataka, India, E-mail: siddhardha.rajahmundry@gmail.com

\begin{abstract}
An arteriovenous malformation is an abnormal tangle of blood vessels in the brain or spine. Some AVM's have no specific symptoms and little or no signs to one's life or health, while others cause severe and devastating effects when they bleed. Treatment options range from conservative watching to aggressive surgery, depending on the type, symptoms and location of the AVM.
\end{abstract}

Keywords: AVM- Arteriovenous Malformation, Brain, Spine

\section{Introduction}

Arteriovenous malformations (AVMs) are vascular abnormalities consisting of fistulous connections of arteries and veins without a normal intervening capillary bed. In the cerebral hemispheres, they frequently occur as cone-shaped lesions with the apex of the cone reaching toward the ventricles. Nearly all AVMs are thought to be congenital. Supratentorial location is the most common $(90 \%)$ [1].

\section{Case Report}

A 16 year old female patient presented to the emergency department with a history of six episodes of epistaxis noticed since 2 days prior to the admission to the hospital. There is no history of trauma,fever or joint pains. Past history revealed recurrent epistaxis with multiple blood transfusions from the age of 8 years and with a history of stroke with right sided hemiplegia and right sided UMN type of facial palsy at the age of fourteen years for which treatment was taken at a local hospital and only supportive treatment was given without imaging. One xamination, child had severe pallor with right hemiparesis. Initial blood counts revealed microcytic hypochromic anemia. Child was advised imaging which revealed complex intracranial AV malformation with a large aneurysm and pressure erosion of the cribriform plate of the ethmoid bone and hypodense per vascular edema noted in posterior limb of left internal capsule.

MR angiogram of brain showed large vascular nidus $(4.4 * 7.8 * 4.2 \mathrm{~cm})$ in left frontal region with extention along the floor of anterior cranial fossa, root of nose on left side, intraparenchymal hematoma $(3.8 * 3.7 \mathrm{~cm})$ multiple cystic areas $(3.8 * 4 \mathrm{~cm})$ in left high parietal region likely to be CSF fluid or arachnoid cyst and $2 \mathrm{~mm}$ midline shift to the right side. Child was stabilised with supportive measures like blood product transfusion and was referred to a tertiary neurological center clipping of the feeding blood vessel was do where in after digital substraction angiography study.

\section{Discussion}

AVMs of the brain are congenital lesions developing during the late somite stages between the 4th and 8 th weeksof life. The lesion consists of persisting direct connections between the arterial inflow and venous outflow without an intervening capillary bed [2]. AVMs

Manuscript received: $25^{\text {th }}$ September 2018

Reviewed: $4^{\text {th }}$ October 2018

Author Corrected: $10^{\text {th }}$ October 2018

Accepted for Publication: $15^{\text {th }}$ October 2018 arise from persistent direct connections between the embryonic arterial and venoussides of the primitive vascular plexus, with failure to developan interposed capillary network $[3,4,5]$.

Genetic variation may influence pathogenesis and the clinical course of brain AVMs [6] Identification of genetic polymorphisms associated with clinical course 
would help instratifying risk and understanding the underlying biology. Molecular studies of brain AVMs have revealed an alterede xpression profile compared with normal tissue, including upregulated expression of genes involved in angiogenesis and inflammation [7]. Brain AVM patients homozygous for the interleukin (IL)-6-174G allele had a greater risk of $\mathrm{ICH}$ at presentation than IL6-174C carriers; a polymorphism in the inflammatory cytokine IL6 was associated with ICH presentation of brain AVM [8]. Local IL6 release by endothelial cells with in the brain AVM nidus may, therefore, contribute tovascular wall instability by stimulating release and activation of matrix metalloproteases $[9,10]$.

Types- There are several types of AVMs:

- Arteriovenous malformation - abnormal tangle of blood vessels where arteries shunt directly into veins with no intervening capillary bed; high pressure.

- Cavernoma - abnormal cluster of enlarged capillaries with no significant feeding arteries or veins; low pressure.

- Venous malformation - abnormal cluster of enlarged veins resembling the spokes of a wheel with no feeding arteries; low pressure, rarely bleed and usually not treated.

- Capillary telangiectasia - abnormal capillaries with enlarged areas (similar to cavernoma); very low pressure, rarely bleed and usually not treated.

- Dural AV fistula - direct connection between one or more arteries and veins into a sinus. The veins of the brain drain into venous sinuses (blood-filled areas located in the dura mater) before leaving the skull and traveling to the heart. Dural AV fistulas and carotidcavernous fistulas (CCF) are the most common[1]

The most common presentation of an AVM is intracerebral hemorrhage (ICH). After $\mathrm{ICH}$, seizure is the second most common presentation. Other presentations of AVMs include headache and focal neurological deficits, which may be related to steal phenomena or other alteration in perfusion in the tissue adjacent to the AVM, such as venous hypertension from arterialization of normal draining veins.

Diagnostic Evaluation- A computed tomography (CT) scan may be used as aninitial screening tool for patients presenting with neurological sequelae related to unruptured or ruptured AVMs. This studycan be used quickly to determine location of the lesion, acute hemorrhage, hydrocephalus, or areas of encephalomalacia from previous surgery or rupture. A non-enhanced CT scanmay show irregular hyperdense areas frequently associated with calcifications in unruptured AVMs and acute haemorrhage on plain CT scan with ruptured AVMs. With the addition of intravenous contrast material, a CT scan can demonstrate the nidus and feeding vessels or dilated drainingveins.

Magnetic resonance imaging (MRI) is superior to CTscan in delineating details of the macro architecture of the AVM, except in the case of acute hemorrhage. These architectural features include exact anatomic relationships of thenidus, feeding arteries, and draining veins as well as topographicrelationships between AVM and adjacent brain[11].

MRI and angiography in combination provide complementary information that facilitates understanding the three-dimensional structure of thenidus, feeding arteries, and draining veins. Complete cerebral angiography with multiple projectionsis a mandatory step in the preoperative evaluation of a patient with an AVM. Cerebral angiography can localize the nidus, the feeding arteries, and draining veins.

Many techniques are available for studying the functionality of cortical structures surrounding the AVM. These include the use of positron emission tomography, functional MRI, magnetoencephalography, and direct provocative testingof cortical function. Judicious use of these techniques will enhance safety of AVM therapy. Such information may allowthe surgeon to tailor treatment modalities to increase the margin of safety during treatment and decrease periprocedural flow-related hemorrhagic or ischemic complications $[1,12]$.

Clearly, one of the most important considerations interms of decision making is the AVM itself. Location, size, and configuration (compact versus diffuse) of the nidus; the pattern and location of the feeding and draining vessels; andthe association of abnormalities, including aneurysms, directarteriovenous fistulae, stenosis, or occlusion of the venous draining system are all factors that must be taken into consideration to estimate not only the risk of surgical excision ofa particular AVM but also the risk of no treatment. To helpthe neurosurgeon estimate the surgical risk, a number of classifications have been developed but the most commonly used classification today is that proposed by Spetzler and Martin [13].

Treatment- The currently used treatments for AVMs include microsurgical resection only, preoperative endovascular embolization followed by microsurgical 
resection, stereotactic radio surgery only, preprocedural endovascular embolization followed by radio surgical treatment, endovascular embolization only, and observation only. The ultimate goal for all ofthese modalities is cure for the patient; however, the only way to achieve cure is with complete obliteration of the AVM. Microsurgical resection, whenever it can be performed safely is the "gold standard" treatment for brain AVMs, and other methods of treatment must be measured against it. Hence, AVM's should also be considered as a possibility while ruling out the causes of epistaxis in children.

Funding: Nil, Conflict of interest: None initiated,

Perission from IRB: Yes

\section{References}

1. Bambakidis NC, Sunshine JL, Faulhaber PF, Tarr RW, Selman WR, Ratcheson RA. Functional evaluation of arteriovenous malformations. Neurosurg Focus11(5): $1-5,2001$.

2. Garretson HD: Intracranial arteriovenous malformations, in Wilkins RH, Rengachary SS (eds): Neurosurgery. New York, Mc Graw-Hill, 1985, pp 2433-2442.

3. Moore KL: The Developing Human: Clinically Oriented Embryology. Philadelphia,Saunders,1982,ed 3

4. Heros RC: Arteriovenous malformations of the brain, in Ojemann RG, Heros RC, Crowell R (eds): Surgical Management of Cerebrovascular Disease. Baltimore, Williams \& Wilkins, 1988, ed 2, pp 347-413.

5. Tew, JM Jr, Lewis AI: Honored guest presentation: Management strategies for the treatment of intracranial arteriovenous malformations. Clin Neurosurg 46:267$284,2000$.
Original Research Article

6. Shenkar R, Elliott JP, Diener K, et al. Differential gene expression in human cerebrovascular malformations. Neurosurgery. 2003 Feb; 52 (2):465-77; discussion 477-8.

7. Hashimoto T, Lawton MT, Wen G, Young GY, Choly T Jr, Stewart CL, Dressman HK, Barbaro NM, Marchuk DA, Young WL: Genemicroarray analysis of human brain arteriovenous malformations. Neurosurgery 54: 410-425, 2004.

8. Pollock BE, Gorman DA, Coffey RJ: Patient outcome after arteriovenous malformation radiosurgical management: Results based on a 5-to 14- year followup study. Neurosurgery 52: 1291-1297, 2003.

9. Dasu MR, Barrow RE, Spies M, Herndon DN: Matrix metalloproteinase expression in cytokine stimulated human dermal fibroblasts. Burns 29:527$531,2003$.

10. Ferroni P, Basili S, Martini F, Cardello CM, Ceci F, DiFranco M, Bertazzoni G, Gazzaniga PP, Alessandri, C: Serum metalloproteinase 9 levels in patients with coronary artery disease:A novel marker ofinflammation. J Investig Med51:295-300, 2003.

11. Leblanc R, Levesque M, Comair Y, Ethier R: Magnetic resonance imaging of cerebral arteriovenous malformations. Neurosurgery21:15-20, 1987.

12. Pouratian N, Cannestra AF, Bookheimer SY, et al. Variability of intraoperative electrocortical stimulation mapping parameters across and within individuals. J Neurosurg. 2004 Sep;101(3):458-66. DOI:10.3171/jns. 2004. 101.3.0458

13. Spetzler RF, Martin NA. A proposed grading system for arteriovenous malformations. J Neurosurg. 1986 Oct; 65 (4): 476-83. DOI:10. 3171/jns. 1986. 65.4 .0476 .

\section{How to cite this article?}

D. Manoj, Venkatasuryanarayana, C.R. Banapurmath. Cerebro arteriovenous malformation presenting as recurrent epistaxis: a rare entity. Int J Pediatr Res.2018;5(10):484-486. doi:10.17511/ijpr.2018.i10.01. 